\title{
Sevoflurane Sedation Using a Nasal Cannula in Pediatric Patients
}

\author{
Sang-Eun Ji', Jong-Soo Kim', Jong-Bin Kim², Seung-Oh Kim³ \\ ${ }^{\prime}$ Department of Pediatric Dentistry, School of Dentistry, Dankook University, ${ }^{2}$ Kizwell Dental Clinic, \\ ${ }^{3}$ Department of Anesthesiology, School of Dentistry, Dankook University
}

\section{Abstract}

A total of 14 children who visited the department of Pediatric dentistry of Dankook University Dental Hospital from January, 2012 to May, 2012 and decided to get dental treatment under inhalation sevoflurane deep sedation, were studied to determine the effectiveness of end-tidal sevoflurane, respiratory and cardiovascular function to analyze monitoring sheets.

The Heart rate (H.R) data were mean $101.4 \mathrm{rate} / \mathrm{min}$ (76.4-135.4 rate/min). The systolic blood pressure data mean were $96.9 \mathrm{mmHg}(84.2-109.2 \mathrm{mmHg})$ and diastolic blood pressure data mean were $50.5 \mathrm{mmHg}$ (34.0$62.0 \mathrm{mmHg}$ ). The Respiration rate (R.R) data mean were $24.4 \mathrm{rate} / \mathrm{min}$ (15.0-36.7 rate $/ \mathrm{min})$. The $\mathrm{SpO}_{2}$ data mean were $99.4 \%$ (97.5-100.0\%). The end tidal $\mathrm{CO}_{2}\left(\mathrm{ETCO}_{2}\right)$ data mean were $27.8 \mathrm{mmHg}(16.4-38.0 \mathrm{mmHg})$. The end-tidal sevoflurane data mean were $1.9 \mathrm{vol} \%$ (1.0-3.4 vol\%).

Key words : Sevoflurane inhalation, Deep sedation, $\mathrm{ETCO}_{2}$, End-tidal sevoflurane, Pediatric dentistry

\section{I. 서 론}

기존에 치과에서는 행동조절이 되지 않는 소아환자에서 아산 화질소(Nitrous Oxide)를 일반적인 흡입 마취제로 사용하고 있다. 아산화질소는 빠르게 진정 상태가 유도되며 회복이 빠르 고 향도 부드럽고 호흡기와 심혈관 기능에 최소한의 영향을 미 친다. 그러나 진정의 효과가 개인에 따라 큰 차이를 보인다는 단점이 있다 ${ }^{1}$. 또한 진정의 깊이를 증가시키기 위해 아산화질소 농도를 $80 \%$ 이상 높이게 되면 흥분, 착란, 저산소증이 흔하다 고 하였다 ${ }^{1)}$.

그러나 전신마취는 마취는 진정법에 비해 실패율이 적지만 침습적이며 마취 후에 소아환자에서 무호흡과 서맥 등의 증상 이 나타날 수 있다 ${ }^{2}$. 또한 회복 시간이 느리며 전신마취로부터 회복하는 환자는 기면, 혼미, 심한 지남력장애, 섬망 또는 흥분 등 다양한 형태의 각성반응을 나타낼 수 있다 ${ }^{3)}$. 심한 각성반응 은 특히 소아에서 더 흔하게 나타난다 ${ }^{4}$.
따라서 의식하진정 보다는 의식수준이 깊게 저하되고 전신마 취보다는 얕게 저하되는 깊은 진정법이 유용하게 사용될 수 있 다. 국소마취를 동반한 깊은 진정법이 치과적 수술에서 전신 마 취의 안전한 대안이 되어 왔다고 했으며 그 이유는 진정법은 전 신마취에 비해, 호흡, 심혈관 기능, 보호 반사, 환자의 협조도에 최소한의 영향을 미치며, 회복도 빠른 장점을 가지기 때문이라 고 했다 ${ }^{1.5,6)}$.

세보플루란(Sevoflurane)이 깊은 진정을 위한 흡입마취제로 서 개발이 되었고 Wallin 등기이 쥐에서 세보플루란를 이용한 연구를 보고한 이후 세보플루란에 관한 많은 연구들이 진행되 었다. 세보플루란은 halomethyl polyfluoroisopropyl ether 그룹의 흡입 마취제로 비교적 비자극적인 냄새로 환자에게 적 용 시 거부감 없이 받아들여질 수 있는 약물이다 ${ }^{8-10)}$. 무엇보다 도 혈액:가스 분배 계수가 성인에서 0.69 , 신생아에서 0.66 으 로 매우 작아 마취 유도와 회복이 빠르며 마취심도를 정확하고 빠르게 조절할 수 있는 장점이 있어 소아 환자와 응급 상황에서 
유용하게 사용할 수 있다 $5,6,11$.

본 논문의 목적은 세보플루란을 이용하여 흡인 진정을 시행 한 총 14 명의 환자들의 마취기록지를 분석하여 심박수(Heart rate), 혈압(Blood pressure), 호흡수(Respiration rate), 산 소포화도 $\left(\mathrm{SpO}_{2}\right)$, 호기말 이산화탄소 농도(End tidal $\mathrm{CO}_{2} \mathrm{vol}-$ ume; $\mathrm{ETCO}_{2}$ )와 호기말 세보플루란 농도(End tidal sevoflurane volume)에 대하여 평가하여 세보플루란을 이용한 흡인 진정의 안정성에 대하여 평가해 보고자 함에 있다.

\section{II . 연구 대상 및 방법}

\section{1. 연구 대상}

2012년 1월 1일부터 2012년 5월 31일까지 단국대학교 치 과대학 부속 치과병원 소아치과에 내원한 환자 중 세보플루란 을 이용한 흡입 진정법을 시행하기로 한 모든 환자를 대상으로 신환기록지, 마취전 평가기록지, 마취기록지를 분석하였다.

\section{2. 진정방법}

환자 보호자에게 깊은 진정에 대한 주의사항을 다시한번 설 명 후 동의서를 받고 진행하였다. 마취유도를 위해 안면 마스크 를 사용하여 산소 $4 \mathrm{~L} / \mathrm{min}$, 아산화질소 $4 \mathrm{~L} / \mathrm{min}$ 속도로 투여 후 고농도의 세보플루란 $8 \mathrm{vol} \%$ 를 주입하여 마취를 유도하였 다. 환아가 눈을 감고 움직임이 없어지면 충분한 진정상태가 되 었다고 판단하고, 아산화질소는 차단하고 세보플루란 3 4 $\mathrm{vol} \%$ 와 산소 $2 \mathrm{~L} / \mathrm{min}$ 의 속도로 주입하였다. 치과 치료를 위해 안면마스크를 경비 캐눌라(HUDSON RCI: Teleflex, NC, $\mathrm{USA}$ (Fig. 1)로 바꿔주고 시술기간 동안 적정 수준의 진정을 유지하기 위해 호기말 세보플루란 농도를 1 2 $\mathrm{vol} \%$ 로 유지하 도록 하였다. 진정 상태 동안 심박수, 혈압, 호흡수, 산소포화 도, 호기말 이산화탄소 농도, 호기말 세보플루란 농도를 5 분 단 위로 모니터링 하여 기록하였다.

\section{III. 결 과}

\section{1. 환자 분포}

여자 1 명, 남자 13 명으로 총 14 명의 환아가 연구에 포함되었 다. 연령 분포는 1 9세이고, 평균연령은 4세이었다. 치료 및 마취시간은 평균 56 분이었고 최소 10 분에서 최대 135 분까지 였다. 전체 환아 중 3 명의 환아는 외상으로 인한 응급치료이었 고 2 명의 환아는 자폐장애를 가지고 있었다. 치과치료 내용으 로는 수복치료, 신경치료, 기성금속관, 발치, 봉합 등이었다 (Table 1).

\section{2. 분석 결과}

모든 환자에서 성공적으로 깊은 진정 하 치과치료를 마칠 수 있었다. 평균 심박수 101.4회/분, 평균 혈압 96.9/50.5 $\mathrm{mmHg}$, 평균 호흡수 24.4회/분, 평균 산소포화도 $99.4 \%$, 평

Table 1. Characteristic of Patients $(\mathrm{N}=14)$

\begin{tabular}{ccccl}
\hline & Sex & Age & MHx & \multicolumn{1}{c}{ Treatment } \\
\hline 1 & M & 1 & N/S & Ext \\
2 & M & 2 & N/S & Suture \\
3 & M & 2 & N/S & Resin op \\
4 & M & 2 & N/S & Resin op, pulpectomy \\
5 & F & 2 & N/S & Suture \\
6 & M & 2 & N/S & Complex odontoma extraction \\
7 & M & 2 & N/S & s/o \\
8 & M & 3 & N/S & Suture \\
9 & M & 4 & N/S & Resin op, pulpectomy \\
10 & M & 5 & N/S & Pulpectomy \\
11 & M & 5 & N/S & Resin op, pulpectomy \\
12 & M & 9 & Autism & Resin op, SSC, ext, B\&L del' \\
13 & M & 9 & N/S & 2 mesiodens extraction \\
14 & M & 9 & Autism & SSC, ext \\
\hline
\end{tabular}

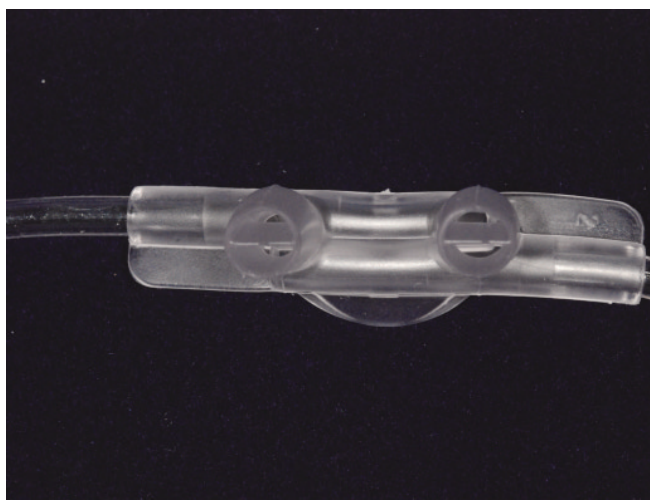

Fig. 1. Nasal cannula application and nasal prong view. 
균 호기말 이산화탄소 농도 $27.8 \mathrm{mmHg}$, 평균 호기말 세보플 루란 농도 $1.9 \mathrm{vol} \%$ 이었다(Table 2).

환자 별 치료과정 중 심박수, 혈압, 호흡수, 산소포화도, 호기 말 이산화탄소 농도, 호기말 세보플루란 농도의 추이 변화는 그

Table 2. Results of sedation data

\begin{tabular}{lrrr}
\hline & Mean & Min & Max \\
\hline Treatment time (min) & 56.0 & 10.0 & 135.0 \\
Heart Rate (rate/min) & 101.4 & 76.4 & 135.4 \\
Systolic Blood Pressure (mmHg) & 96.9 & 84.2 & 109.2 \\
Diastolic Blood Pressure (mmHg) & 50.5 & 34 & 62.0 \\
Respiratory Rate (rate/min) & 24.4 & 15.0 & 36.7 \\
$\mathrm{SpO}_{2}(\%)$ & 99.4 & 97.5 & 100.0 \\
$\mathrm{ETCO}_{2}$ (mmHg) & 27.8 & 16.4 & 38.0 \\
End tidal sevoflurane (vol\%) & 1.9 & 1.0 & 3.4 \\
\hline
\end{tabular}

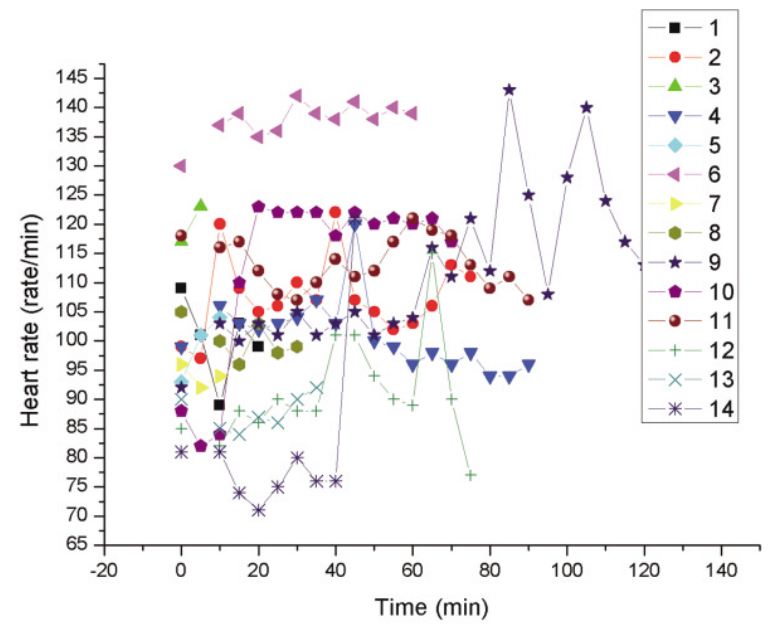

Fig. 2. Heart rate change during sevoflurane sedation for each patients.

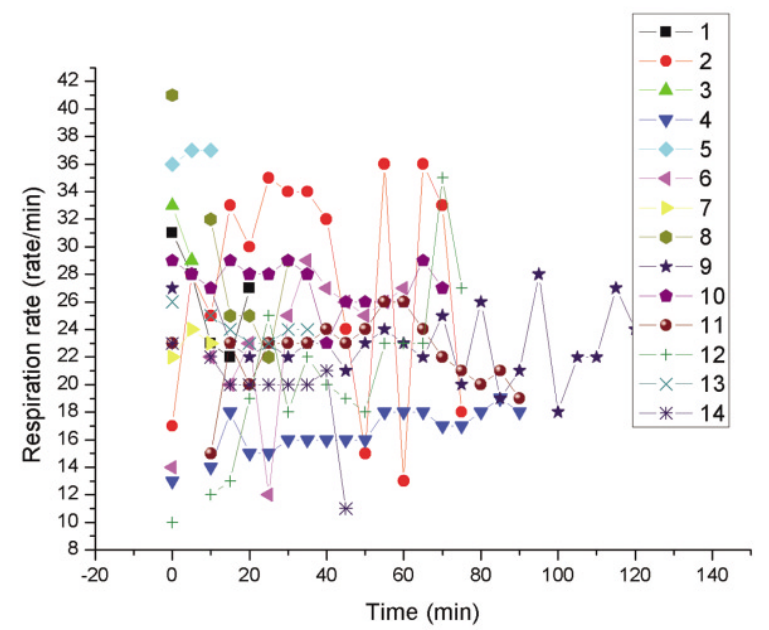

Fig. 4. Respiration rate change during sevoflurane sedation for each patients.
래프를 통해 나타내었다(Fig. 2 7).

모든 환자는 세보플루란 중단 후 5 분 내에 의식을 회복하였 고 회복실에서 완전히 회복되는 것을 확인한 후 귀가하였다. 다 른 합병증은 발견되지 않았다.
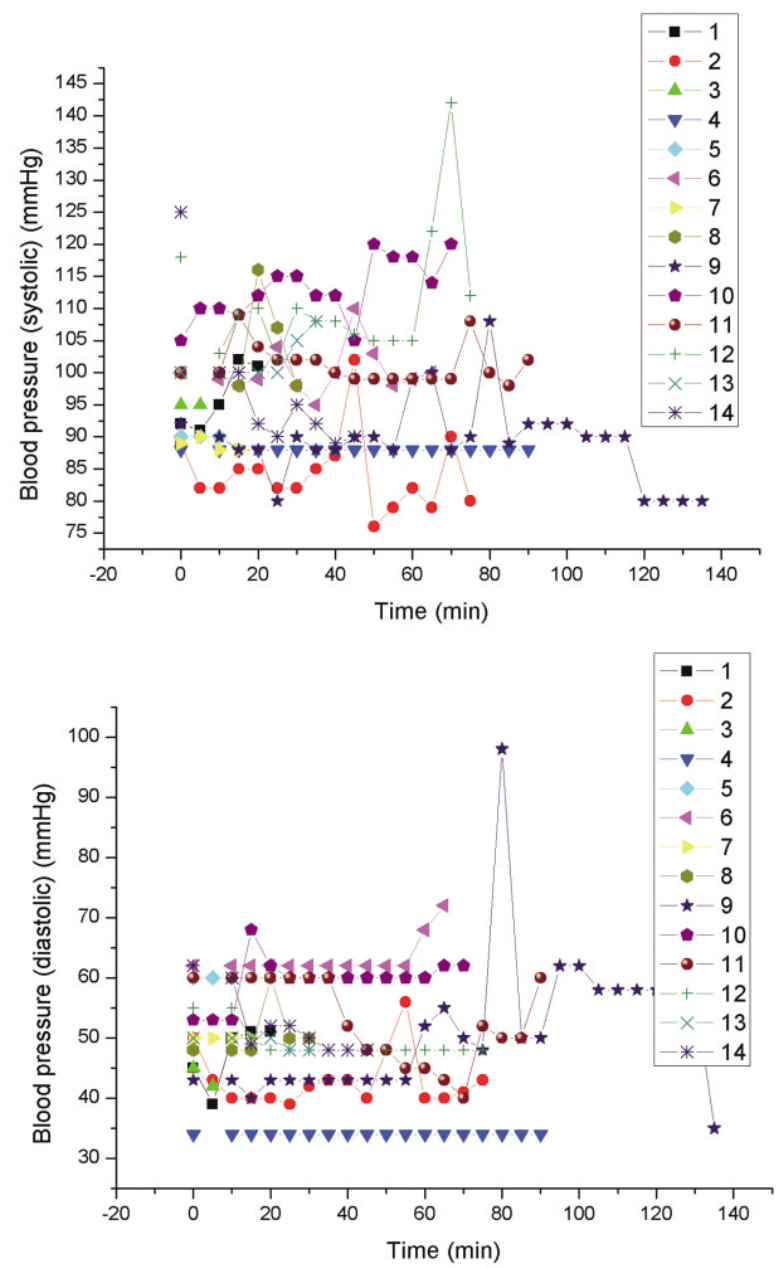

Fig. 3. Blood pressure change during sevoflurane sedation for each patients.

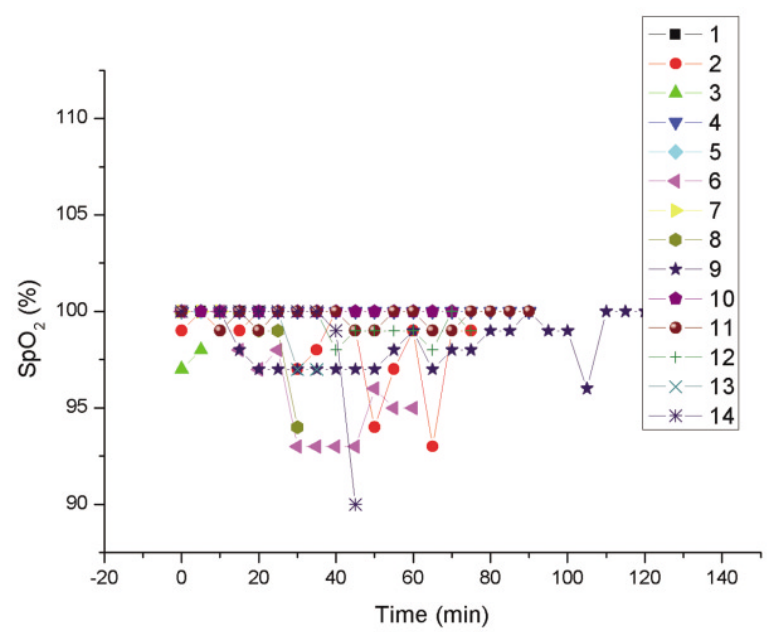

Fig. 5. $\mathrm{SpO}_{2}$ change during sevoflurane sedation for each. 


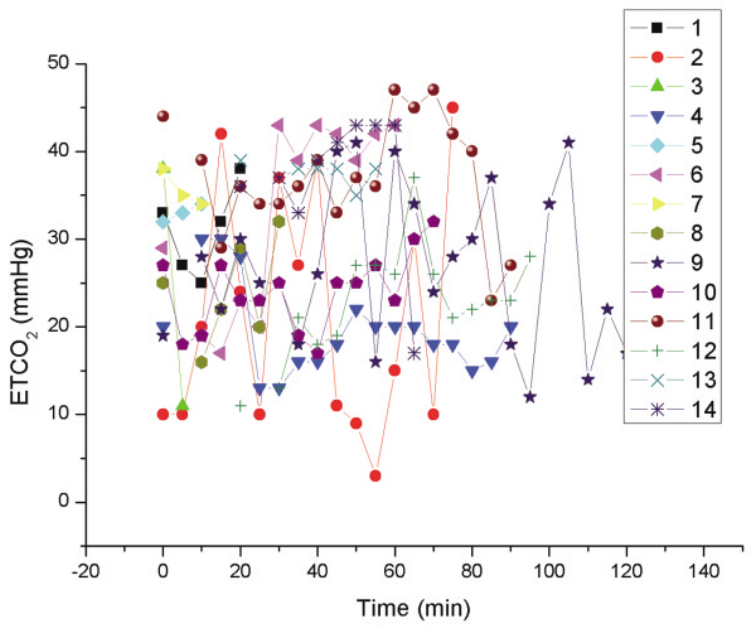

Fig. 6. $\mathrm{ETCO}_{2}$ change during sevoflurane sedation for each patients patients.

\section{IV. 고 찰}

이상적인 흡입 마취제는 마취 유도가 빠르고, 회복이 빨라야 하며, 마취 깊이를 빠르게 조절할 수 있어야 한다. 또한 치료지 수 즉, 안전역이 넓어야 하고 일반적으로 사용하는 용량에서 독 성작용이나 부작용이 없어야 한다 ${ }^{12}$.

세보플루란은 흡입마취제로서 가져야 할 이상적인 특징들을 모두 가지고 있는 약물로 최근에 많이 사용되어지고 있는 추세 이다. 기존에 세보플루란은 전신마취 전 유도 시와 신생아나 조 산아의 $\mathrm{MRI}$ 검사 등의 검진을 위해 사용되어 왔고 최근에 치과 분야에서 세보플루란을 단독으로 사용한 깊은 진정으로 범위가 확대되고 있다 ${ }^{5)}$.

세보플루란은 마취의 유도와 회복이 빠르고 진정의 깊이 조 절이 용이하며 심혈관계 안전성이 높아 소아 환자에서 적용하 기 유리하다 ${ }^{5,6,11}$.

Wallin 등 ${ }^{8}$ 은 세보플루란을 단독으로 이용하였을 때 마취 유 도시간이 15 30분이었고, Smith 등 ${ }^{13)}$ 은 세보플루란과 아산화 질소를 동시에 투여했을 때 109초 만에 마취유도가 되었다고 하였다. 본 연구에서는 세보플루란을 아산화질소와 동시에 투 여하여 진정을 유도하였고 평균 5 분 이내에 원하는 정도의 진 정상태를 유지할 수 있었다.

본원에서 세보플루란을 이용한 흡입 진정으로 치과치료를 진 행하기로 한 환자는 3세 미만의 협조전 단계, 외상으로 인하여 응급 치료가 들어가야 하는 상황에서 환자의 행동조절이 되지 않을 경우와 자폐증의 의학적 병력이 있어 협조가 불가능한 경 우 등이 있었다. 아이가 외상 직후 흥분한 상태이거나 자폐증이 있는 다소 덩치가 큰 아이는 일반적인 경구투여를 통한 진정방 법을 시도해 보았을 때 약을 먹기 거부하여 실패하는 경우가 많 다. 또한 주어진 용량을 다 먹이기 힘들어 원하는 수준의 진정을

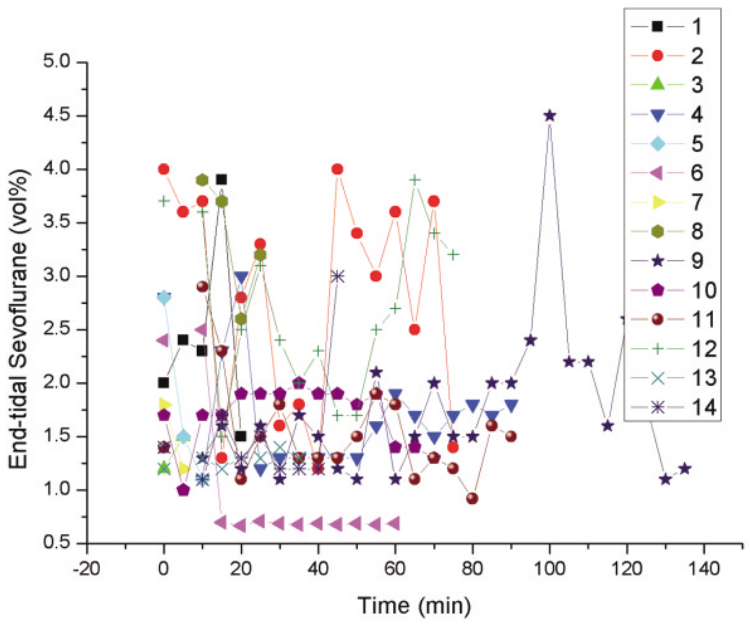

Fig. 7. End tidal sevoflurane volume change during sevoflurane sedation for each patients.

얻기 힘든 경우가 많다. 세보플루란은 이러한 상황의 환자에게 적용이 편하고 마취 유도가 빨라 유용하게 사용할 수 있었다.

세보플루란을 이용한 흡입진정 시에는 철저한 모니터링이 반 드시 수반되어야 한다. 모니터링은 환자의 혈압, 환기상태, 심 혈관계 등에 이상이 생겼을 경우 임상적으로 심각한 상황이 되 기 전에 초기에 감지할 수 있으므로 중요하다. 깊은 진정 상태 에서는 기도폐쇄나 무호흡이 발생할 수 있기 때문에 산소포화 도와 호기말 이산화탄소 농도 측정을 하여 위험을 사전에 예방 할 수 있어야 한다 ${ }^{14)}$

진정 과정 중 환자의 혈역학적 상태를 평가하기 위해 심박동 수와 혈압의 모니터링이 반드시 필요하다 ${ }^{14}$. 일반적인 금식과 마취제는 마취과정 중 환자가 저혈량성 상태가 되는 경우 환아 스스로 조절할 수 있는 능력을 다소 둔화시킬 수 있다. 따라서 조기에 심박동수와 혈압의 변화를 감지하여 심혈관허탈의 위험 이 생기지 않도록 예방하여야 한다. 본원에서 진행한 총 14 명 의 환아 모두 치료기간 동안 심박동수와 혈압이 매우 안정적으 로 유지되었다. 의식 정도의 측정이 어려운 깊은 진정에서 심박 동수의 변화는 진정 실패의 전구증상으로 유용하게 사용할 수 있다.

호흡수 역시 호흡 감시를 위한 지표로 중요하게 사용된다. 진 정이 깊어지게 되면 호흡수가 감소하게 되는데 과진정시 호흡 수 감소는 호흡부전을 예측할 수 있지만, 개방식 흡입투여에 있 어 호흡수 감소와 호흡량의 감소는 환자에게 흡입 진정제인 세 보플루란 투여량의 감소로 이어진다. 이러한 과정을 반복하면 서 자가 호흡에 의해 진정의 깊이를 적절한 수준으로 조절할 수 있다. 이는 개방식 투여에 있어 적정 유량과 농도가 정해지면 진정의 깊이를 환자 스스로 조절이 가능하게 된다는 것이다 (Autoregulation). 본 증례에서는 평균 호흡수는 분당 24.4회, 최소값은 분당 15 회로 진료시간 중 실시간으로 감시한 호흡수 
의 변동이 다소 많았으나 무호흡이나 호흡부전이 생길만큼 심 각한 호흡 수 저하는 없었으며 비교적 호흡유지가 잘되었다.

산소포화도 역시 흡입 진정 시 환자의 호흡 상태를 평가하는 데 도움을 준다. 이번 증례에서는 산소포화도가 평균 $99.4 \%$, 최소 $97.5 \%$ 로 안정적으로 호흡이 유지되었다. 전체 치료 과정 에서 산소포화도가 $94 \%$ 이하로 떨어진 경우는 총 14 명의 환자 들 중 한 명의 환자에서 치료 도중 $93 \%$ 로 한 번 떨어졌는데 Chin lift 방법을 통한 기도 확보 후 바로 $96 \%$ 로 회복되었다. 이는 기도유지가 되지 않은 상황으로 기도폐쇄로 인한 저산소 증 상태라 볼 수 있다. 따라서 진정과정 동안 기도유지를 지속 하는 것이 매우 중요하다.

진정과 전신마취에 사용되는 약물은 심혈관계의 억제작용보 다 중추신경계와 호흡 억제에 큰 영향을 미치기 때문에 심혈관 계의 변화가 나타나기 전에 일반적으로 호흡의 변화가 먼저 관 찰된다. 따라서 호흡계의 감시가 가장 중요하며 이 중 호기말 이산화탄소 농도는 환아의 호흡이 유지되고 있는 상태를 가장 빠르게 인지할 수 있는 방법으로 흡입 마취의 유효성을 평가하 기 위한 가장 중요한 지표이다.15). 호기말 이산화탄소 농도의 정상범위는 $35 \sim 45 \mathrm{mmHg}$ 이고, 진정 시에는 호흡량이 적어지 면서 정상범위가 40 50 mmHg로 약간 증가된다. 본 연구에 서는 호기말 이산화탄소 농도가 평균 $27.8 \mathrm{mmHg}$ 로 정상 값에 비해 조금 낮게 측정되었다. 이는 이번 증례들은 기관내 삽관을 통한 정확한 호기말 이산화탄소 농도를 측정한 것이 아니라 세 보플루란 투여와 호기말 이산화탄소 감시가 동시에 가능한 특 수한 경비 캐눌라를 이용한 측정이었기 때문으로 생각된다. $\mathrm{ETCO}_{2} \mathrm{HUDSON}_{\mathrm{RCI}}$ 경비 캐눌라는 sampling tube에서 두 개의 nasal prong으로 나누어져 각 각 하나씩 하나의 콧구멍으 로 적용된다. 각각의 nasal prong은 다시 반으로 나눠져 한쪽 에서는 산소와 세보플루란이 흡입 되고 다른 한쪽에서는 호기 가스가 나와 sampling을 할 수 있게 디자인 되었다(Fig. 1). 따라서 호기말 이산화탄소 농도를 측정하는 동안 바로 위에서 는 흡입 가스가 지속적으로 흡입되고 있는 상황이어서 호기말 이산화탄소 농도는 투여되는 산소와 대기 중의 공기에 의하여 희석이 되어 값이 다소 낮게 나왔다고 생각해 볼 수 있다 ${ }^{2)}$. 그 러므로 호흡 패턴이 일정하고 호기말 이산화탄소 농도가 20 $\mathrm{mmHg}$ 이상 검출이 되면 호흡이 비교적 안정적인 상태라 보고 진료가 진행되었다.

또한 소수의 증례에서 호기말 이산화탄소 농도가 평균값에서 큰 폭으로 증가했다가 감소했다가 다시 증가하는 반복적인 경 향을 확인할 수 있었다. 세보플루란을 이용한 깊은 진정법은 전 신마취와는 달리 환자 스스로 자발적인 호흡을 유지하게 되는 데, 흡입한 세보플루란의 농도가 높아서 과진정 상태가 오게 되 면, 과진정으로 인해 호흡이 줄어들게 되고, 이로 인해 자연스 럽게 흡입진정약물의 흡입이 감소함으로써 진정의 깊이가 감소 하게 된다. 진정이 얕아지게 되면 다시 호흡량이 증가하게 되고 흡입진정약물의 흡입도 증가하여 진정의 깊이가 다시 증가하게 된다. 이러한 과정을 계속 반복하면서 자가 호흡에 의해 진정의 깊이를 적절한 수준으로 조절할 수 있게 된다. 따라서 호기말
이산화탄소 농도가 평균값에서 큰 폭으로 증가했다가 감소했다 가 다시 증가하는 반복적인 경향은 진정깊이와 호흡량의 반비 례 상관관계로 생기는 진정깊이를 일정수준으로 이루는 자가 호흡조절에 의한 것으로 생각해 볼 수 있다.

경비 캐눌라로 많은 양을 투여할 경우 유효한 양의 투여는 유 리하지만 대기의 오염이 문제이다. 그러므로 적정 유량과 적정 세보플루란의 농도 조절이 진정수행의 성공에 있어 핵심이다. 경비 캐눌라를 이용한 세보플루란을 흡입하는 과정에서 세보플 루란 흡입 가스는 구호흡이나 대기 가스와의 흡입에 의해 농도 가 희석되기에 투여농도는 $4 \mathrm{vol} \%$, 투여 가능 유량은 2-4 $\mathrm{L} / \mathrm{min}$ 으로 하고, 실질적으로 유효한 호기말 세보플루란 농도 를 측정하여 투여가스의 농도와 유량을 조절하였다.

Sury 등른 성공적인 자기 공명 영상 이미지를 얻기 위해, 코와 입에 sampling tube가 부착된 Smart Capnoline ${ }^{\mathrm{TM}} \mathrm{O}_{2}$ 장치를 이용해 세보플루란 흡입진정을 유도하였는데 평균 $4 \%$ 의 세보플루란을 흡입할 때, 13 명 중 12 명의 유아에서 성공적 인 진정을 보였다고 하였다. De Sanctis Briggs ${ }^{15)}$ 역시 자기 공명 촬영 검사를 위해 12 개월 미만의 영아에게 $2 \mathrm{~L}$ 아산화질 소, $2 \mathrm{~L}$ 산소와 $7 \%$ 세보플루란을 이용하여 깊은 진정을 유도 하였고 안면마스크를 통하여 호기말 세보플루란 농도를 $1.8 \sim 2 \%$ 로 유지하였을 때 640 케이스 중에서 $97.96 \%$ 의 성공 률을 보였다고 하였다. 다만 본원에서는 치과 치료의 특성상 안 면마스크 대신에 경비 캐눌라를 사용하였으며 이때 평균 호기 말 세보플루란 농도가 $1.9 \mathrm{vol} \%$ 이었고 모든 환자에서 $1.0 \sim 3.4 \mathrm{vol} \%$ 를 유지하여 성공적인 진정을 유지할 수 있었 다. 호기말 세보플루란 농도는 실질적인 호기말 농도라기보다 투여하는 경비캐눌라의 특성상 투여부위와 검출부위가 병합되 어 있는 형태로서(Fig. 1) 고정된 분당 $2 \mathrm{~L}$ 의 산소유량과 $4 \%$ 의 세보플루란 농도의 경비캐눌라 투여에 있어, 호흡량이 적을 수록 캐눌라로 투여하는 세보플루란의 농도를 많이 반영되고 호흡량이 많을수록 호기량 비율이 증가하므로 체내 세보플루란 의 농도를 많이 반영할 것으로 추정된다. 실질적으로 폐내 세보 플루란의 농도는 경비캐눌라로 감시되는 농도보다 낮을 것으로 분석된다.

세보플루란은 마취 회복 시 구토나 구역의 부작용을 일으킨 다는 보고 ${ }^{16)}$ 가 있으나 본원의 환자 모두에서는 특이할만한 부작 용을 보이지 않았다.

그러나 sevoflurane은 안전역이 좁기 때문에 철저한 모니터 링이 반드시 수반되어야 하며 응급상황에서 대처할 수 있는 장 비와 전문인력이 반드시 구비되어 있어야 할 것이다.

\section{V. 결 론}

행동 조절이 어려운 깊은 진정이 필요한 소아환자에서 특수 한 경비캐눌라를 이용한 세보플루란 진정시 호기말 세보플루란 농도를 1 2 vol\%로 유지하였을 때 적절한 깊이의 진정을 얻 을 수 있었고 그 과정에서 안정적인 호흡과 활력징후를 보이며 다른 부작용은 관찰되지 않아 치과치료 시 유용하게 사용될 수 
있을 것으로 생각된다.

\section{References}

1. Naohisa H, Hirohisa F, Kumiko O : Inhalation Sedation with Sevoflurane: a comparative study with nitrous oxide. J Oral Maxillofac Surg, 53:2426, 1995.

2. Michael RS, Helen H, Mark LT : Sevoflurane sedation in infants undergoing MRI: a preliminary report. Pediatr Anesth, 15:16-22, 2005.

3. Barash PG, Cullen BF, Stoelting RK : Clinical anesthesia, 3rd ed. philadelphia, Lippincott-Paven. 1300, 1997.

4. Chung F, Seyone G, Dyok B, et al. : Age related cognitive recovery after general anesthesia. Anesth Analg, 71:217, 1990.

5. Kim SO, Kim YJ, Kim YS : Deep sedation with sevoflurane insufflated via a nasal cannula in uncooperative child undergoing the repair of dental injury. Am J Emerg Med, 31:894.e1-e3, 2013.

6. Kim SO : A survey of general anesthesia, sevoflurane sedation and intravenous sedation in chungnam dental clinic for the disabled. $J$ Korean Academy of Pedi Dent, 40:28-39, 2013.

7. Wallin RF, Regan BM, Napoli MD, et al. : Sevoflurane: a new inhalational anesthetic agent. Anesth Analg, 54:758-765, 1975.

8. Jones RM : Desflurane and sevoflurane: inhalation anesthetics for this decade? Br J Anesth, 65:527536,1990

9. Yurino M, Kimura H : Efficient inspired concentra- tion of sevoflurane for vital capacity rapid inhalation induction(VCRII) technique. $J$ Clin Anesth, 7:22831, 1995.

10. Doi M, Ikeda K : Airway irritation produced by volatile anesthetics during brief inhalation: comparison of halothane, enflurane, isoflurane and sevoflurane. Can J Anaesth, 40:122-126, 1993.

11. Frink EJ, Malan TP, Atlas T, et al. : Clinical comparison of sevoflurane and isoflurane in healthy patients. Anesth Analg, 74:241-245, 1992.

12. Montes RG, Bohn RA. : Deep sedation with inhaled sevoflurane for pediatric outpatient gastrointestinal endoscopy. J Pediatr Gastroenterol Nutr, 31:41-46, 2000.

13. Smith I, Ding Y, White PF. : Comparison of induction, maintenance and recovery characteristics of sevoflurane-N2O and propofol-sevoflurane-N2O with propofol-sevoflurane-N2O anesthesia. Anesth Analg, 74:253-259, 1992.

14. Jeffrey B, Peter L, Richard T, et al. : Practice Guidelines for Sedation and Analgesia by NonAnesthesiologists. An updated Report by the American Society of Anesthesiologists Task Force on Sedation and Analgesia by Non-Anesthesiologists. Anesth Analg, 96:1004-1017, 2002.

15. De Sanctis Briggs V. : Magnetic resonance imaging under sedation in newborns and infants: study of 640 cases using sevoflurane. Pediatr Anesth, 15:915, 2005.

16. Palazzo MGA, Strunin L : Anesthesia and emesis. I: etiology. Can Soc J Anaesth, 31:178-187, 1984. 
국문초록

\title{
소아환자에서 경비 캐눌라를 이용한 세보플루란 흡입 진정
}

\author{
지상은 ${ }^{1} \cdot$ 김종수 $^{1} \cdot$ 김종빈 $^{2} \cdot$ 김승오 $^{3}$
}

${ }^{1}$ 단국대학교 치과대학 소아치과학교실, ${ }^{2}$ 키즈웰치과, ${ }^{3}$ 단국대학교 치과대학 치과마취과학교실

본 연구는 단국대학교 치과병원 소아치과에 2012년 1월부터 2012년 5월까지 내원한 환자 중 세보플루란을 이용한 깊은 진정으로 치과치료를 받은 환자 총 14 명의 마취기록지를 분석하여 적정 수준의 진정을 얻기 위한 유효한 세보플루란의 농도 를 측정하고 진정 과정 중의 호흡 및 심혈관계 평가를 통해 안정성을 평가해 보고자 함에 있다.

심박수(Heart rate)는 평균 101.4회/분(76.4 135.4회/분)을 보였다. 혈압(Blood pressure)은 수축기혈압은 평균 $96.9 \mathrm{mmHg}(84.2 \sim 109.2 \mathrm{mmHg})$, 이완기혈압은 평균 $50.5 \mathrm{mmHg}(34.0 \sim 62.0 \mathrm{mmHg})$ 를 보였다. 호흡수 (Respiration rate)는 평균 24.4회/분(15.0 36.7회/분)을 보였다. 산소포화도 $\left(\mathrm{SpO}_{2}\right)$ 는 평균 99.4\%(97.5 100.0\%)를 보였다. 호기말 이산화탄소 농도(end tidal $\mathrm{CO}_{2}$ volume; $\mathrm{ETCO}_{2}$ )는 평균 $27.8 \mathrm{mmHg}(16.4 \sim 38.0 \mathrm{mmHg}$ )를 보였다. 호 기말 세보플루란 농도(end tidal sevoflurane volume)는 평균 1.9 vol\%(1.0 3.4 vol\%)를 보였다.

주요어: 세보플루란 흡입, 깊은진정, 호기말 이산화탄소 농도, 호기말 세보플루란 농도, 소아치과 